\title{
Usability Analysis of Kahoot in Mathematics Education
}

\author{
Lucas dos Santos Teotônio ${ }^{1}$ \\ Aislânia Alves de Araújo ${ }^{2}$, Jucelio Soares dos Santos ${ }^{3}$ \\ ${ }^{1}$ Universidade Estadual da Paraíba (UEPB) \\ ${ }^{2}$ Faculdade de Filosofia, Ciências e Letras de Cajazeiras (FAFIC) \\ ${ }^{3}$ Universidade Federal de Campina Grande (UFCG) \\ \{lucasuepb, aislanialves\}@gmail.com, \\ jucelio@copin.ufcg.edu.br
}

\begin{abstract}
In this paper, we analyze the level of usability of Kahoot in the classroom context. For this, we select/adapt questions in the area of Mathematics, and its Technologies present in the "Exame Nacional do Ensino Médio" and, we apply these questions in a traditional way (paper-and-pencil) and in a gamified way through Kahoot. We elaborated/applied a survey to the participants to verify the level of usability of the instruments. As a result, the Kahoot tool demonstrated time savings, Ease of use, and promoted greater Satisfaction when comparing the application on paper-and-pencil. The participants considered the use of Kahoot to be more comfortable, exciting, satisfying, and encouraging learning better than the paper-and-pencil method.
\end{abstract}

Keywords: usability; kahoot; mathematics.

Resumo. Neste artigo, analisamos o nível de usabilidade do Kahoot no contexto de sala de aula. Para isso, selecionamos/adaptamos questões da área da Matemática, e suas tecnologias presentes no Exame Nacional do Ensino Médio e, aplicamos essas questões de forma tradicional (papel e lápis) e de forma gamificada. através do Kahoot. Elaboramos/aplicamos um survey aos participantes para verificar o nível de usabilidade dos instrumentos. Como resultado, a ferramenta Kahoot demonstrou economia de tempo, facilidade de uso e promoveu maior satisfação na comparação da aplicação em papel-e-lapis. Os participantes consideraram o uso do Kahoot mais confortável, estimulante, satisfatório e encorajador da aprendizagem melhor do que o método do papel e lápis.

Palavras-chave: usabilidade; kahoot; matemática.

\section{Introduction}

The school is experiencing a conflicting moment, in which it is unable, most of the time, to meet the needs of its students. The student's critical sense is not well developed, and institutions are concerned only with fragmented and repetitive content that does not arouse the student's interest in these themes [Silva et al. 2018].

According to data released by the Ministry of Education (MEC), it reveals that approximately $70 \%$ of high school students have poor performance in the subjects of 
Portuguese and mathematics [Brasil 2018]. A study by [Lima 2018], with students from the first, second, and third grades of high school, reveals the students' difficulty in the discipline of mathematics. A good part of the students involved did not know actual contents of primary education, such as performing operations with fractions, factoring with integers, defining the sequence of the first five prime numbers, calculating the least common multiple and the greatest common divisor.

Technology can be a precursor to improve this scenario. However, it is still a challenge for many educators to work with it, as a survey of 20 higher education teachers in the city of Uberaba-MG reveals three problems faced by teachers. The first one concerns the lack of mastery of the use of technologies that, according to $100 \%$ of those surveyed, still presents the most significant difficulty faced. The other refers to the number of classes and the amount of content to be worked on, according to 50\% of the interviewees, the ideal is to increase the workload to work more closely with related content, and the third demonstrates that $75 \%$ of educators have some fear of not meeting the expectations of students in using technology in their pedagogical practices [Rosa 2013].

Based on this discussion, we formulated the question that guided this paper: which pedagogical approaches influence the active participation and learning of students, in the classroom, in the discipline of mathematics? Given the scenario addressed, educational software helps teachers and promotes student performance/engagement through playful, competitive environments and, at the same time, provides alternative feedback. One strategy that can provide this environment is gamification. It is an emerging concept based on the popularity of games and their inherent abilities to motivate action, solve problems, and enhance learning in the most diverse areas of knowledge and people's lives [Fardo 2013]. This method consists of using elements of games in a context that does not involve them [Deterding et al. 2011].

In this paper, we use Kahoot because it is a web application platform where it is possible to develop quizzes - questionnaires with questions and alternative answers. These quizzes can be used in the classroom and aim to gamify the learning space. We chose Kahoot because it is a simple tool, easily accessible, and has a free version - taking into account that the context of the application of this study is a public school.

We analyze the level of usability of Kahoot in the classroom context. For this, we select/adapt questions in the area of Mathematics and its Technologies present in the "Exame Nacional do Ensino Médio" (ENEM) and, we apply these questions in a traditional way (paper-and-pencil) and in a gamified way through Kahoot. We elaborated/applied a Survey to the participants to verify the level of usability of the instruments.

We organized this paper as follows. In Section 2, we present the related work. In section 3, we present the Kahoot. In section 4, we present the experience report. In section 5, we present the methodology applied to conduct in this paper. In section 6 , we offer the results and their discussions. Finally, in Section 7, we present the conclusions.

\section{Related Work}

In a study produced by [Pereira et al. 2019], a scientific experiment was developed with higher education students from the computer science course, to ascertain the performance 
of these students. The class was divided into two groups with similar academic performance, where the first one answered the questions of the discrete mathematics discipline through Kahoot. At the same time, the second asked the same questions through paper and pencil. At the end of the experiment, verified the group that answered with Kahoot answered more questions than the group that did the activity using paper and pencil.

The paper by [Silva et al. 2018] involved a class from a technical course in high school chemistry at an institution in the state of Ceará. The class was divided into five groups, using the Kahoot tool to create a competitive space and adopting a scoreboard that, according to the total points, would be converted into a score. At the end of the process, the groups got marks above six after the conversion, the main contribution being to promote interaction and collaboration of students in the classroom.

In a study by [Wiener and Campos 2018] developed a study carried out with students from the information technology area using the Colligo App, which allows the creation of classes, where the teacher can create questionnaires so that students can access. From the activities carried out by the students, the tool assigns a score in order to generate rankings, achievements, badges. The results obtained through a survey carried out with the students demonstrated that $80 \%$ felt satisfied with the functionalities of the application. In the author's view, students were very excited to answer the activities and that they asked the teacher questions in order to earn more points on the tool.

\section{Kahoot}

Kahoot is an educational software to support teaching, developed by a team of scientists from Norway [Kahoot 2019]. Its application is multiplatform and has a free version. Its primary focus is the creation of quizzes in the form of quizzes, which is a type of game in which players try to answer correctly the questions offered to them. In Figure 1, we present the initial interface.

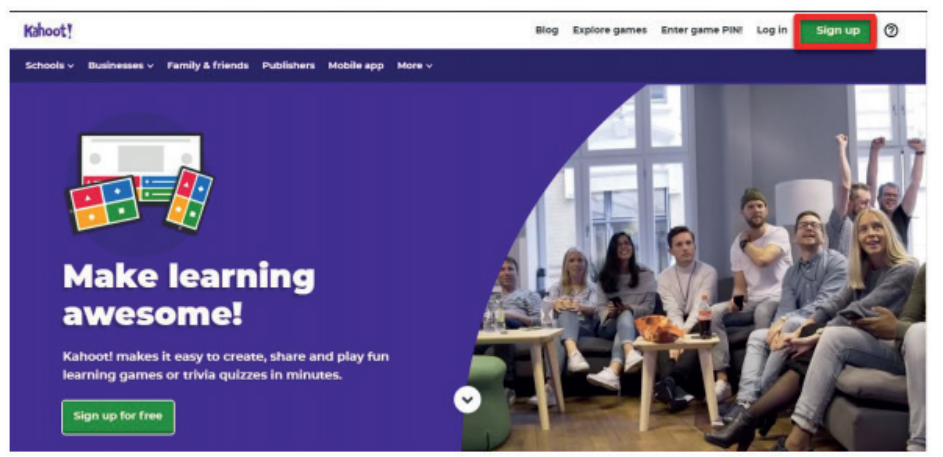

Figure 1. Kahoot' home screen

The application in the classroom is made using equipment that can project a screen so that it is visible to all students, such as a multimedia projector or television. Students using a smartphone or notebook with internet access, enter the game via a PIN code. The student can access made through the Kahoot application, or the browser, by typing the address: https://kahoot.it. The user enters the PIN code, informs a nickname, and clicks 
the button "Ok, go!". Then, the user accesses the waiting screen, informing that he is accessing the game, and waiting for the start of the game.

With a quiz ready, the teacher can perform in the classroom. The questions are asked according to how the teacher predefined their creation. In Figure 2, we show the projection of the quiz. Students visualize the question and its alternatives, analyze which is the correct question and answer by selecting one of the colours (red, blue, yellow, and green) on the device with geometric figures in the centre (triangle, rhombus, circle, and square) respectively associated with each colour.

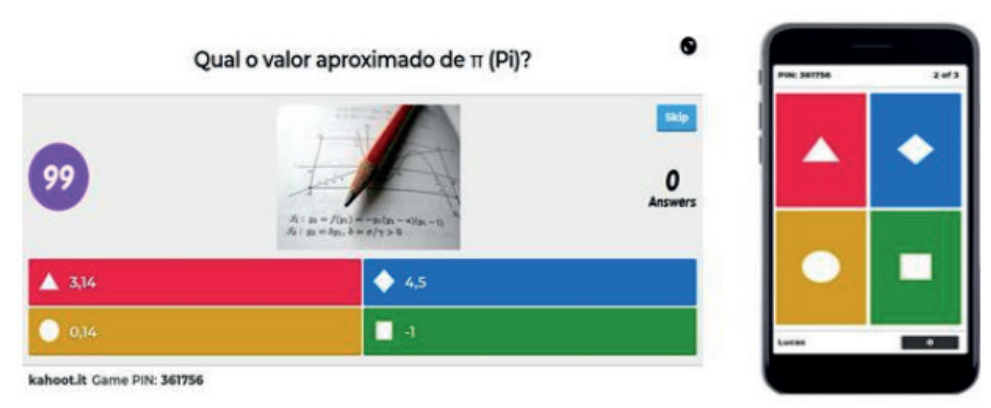

Figure 2. View of the shared screen and smartphone

When all players answer the question or time is up, the tool shows a graph of the players' responses and a partial ranking with the top 5. The scoring criteria of the tool take into account the time spent responding and the correctness of the question, that is, the shorter the response time taking into account that it is correct, the more points the user gets, in case the question is wrong the total points he gets in the round is zero.

In Figure 3, we can observe a) the table of alternatives marked by the participants and the right question, which in the image points to the red option. The applicator can move to the next page by clicking on the b) "Next" button, once this is done, the screen with c) the partial ranking will be displayed.

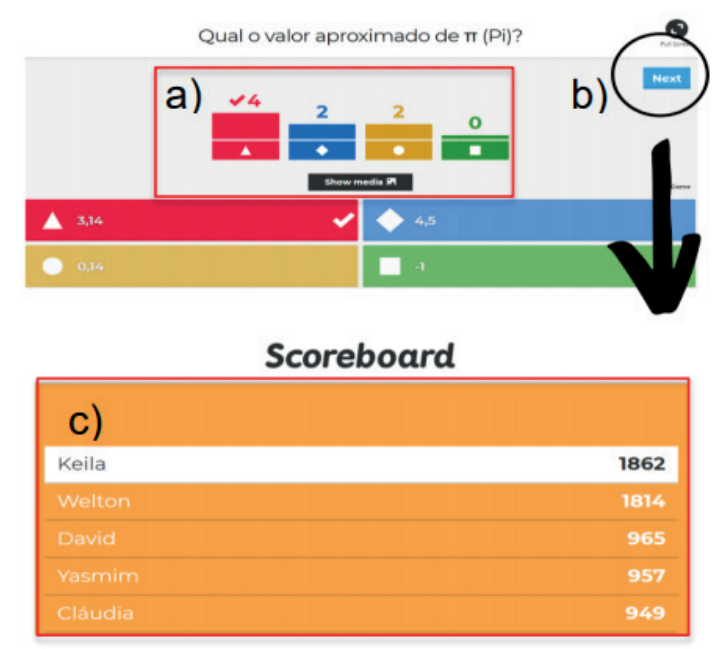

Figure 3. Interface graphs and rankings in Kahoot 
The tool applied in the educational field has many positive points, Kahoot streamlines classes and attracts a more curious and attentive look at the content presented, as well as it brings up the use of logical reasoning for the choice of alternatives, in addition to arousing the desire to do their best to achieve a good score in the ranking [Nascimento 2018].

\section{Experience Report}

In this section, we present the study carried out with students from the 3rd year of high school at Escola Monselhor Vicente Freitas, Pombal, Paraíba, Brazil. We selected the issues present in ENEM in the area of Mathematics and its technologies. In Figure 4, we present an example of a question used in Kahoot.

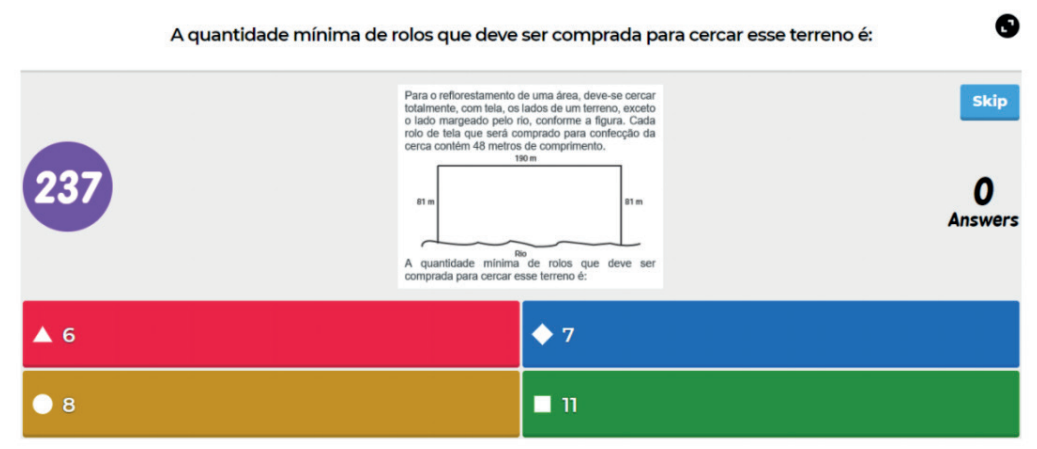

Figure 4. Kahoot question example

Moreover, we adapted the questions on Kahoot and paper. We applied the study in two interventions (on different days). We applied the same number of questions in both methods, which took an average of 40 minutes. Thus, we applied ten questions in the 1 st intervention and eight in the 2nd intervention.

We selected 60 students from three different classes with the following inclusion criteria: age group 16 to 18 years old and have a smartphone for use in the classroom. In each intervention, participants answered both Kahoot and paper-and-pencil questions. We showed that the questions were different in the two methods.

In the interventions, the application through the paper-and-pencil occurred smoothly, without any apparent problem or setback, we were already spreading this type of behaviour since students commonly use this resource. In the gamified process, through Kahoot, we noticed some occurrences during the application. Some students reported having unintentionally marked the questions, and the irregularity of the Internet, at certain times, was an obstacle in the production of the data, as we realized that the tool did not compute $2 \%$ of the questions.

During the application, we noticed more active participation by students in Kahoot when compared to the paper and pencil method. We observed that the students were more excited about each question, especially when the tool displayed the partial leaderboard in which the names of the students with the best score appeared on the screen. We present the results of these interventions in Table 1. We noticed that there was an increase in interest among students in the application using Kahoot that directly impacted the number of correct answers. 
Table 1. Performance between groups in Experiment

\begin{tabular}{|l|c|c|c|c|c|c|}
\hline \multirow{2}{*}{ Intervention } & \multicolumn{3}{|c|}{ Paper-and-Pencil } & \multicolumn{3}{c|}{ Kahoot } \\
\cline { 2 - 7 } & Average & $\begin{array}{c}\text { Standard } \\
\text { Deviation }\end{array}$ & Hits\% & Average & $\begin{array}{c}\text { Standard } \\
\text { Deviation }\end{array}$ & Hits\% \\
\hline First intervetion & 4.37 & 1.36 & $43 \%$ & 4.44 & 1.96 & $44 \%$ \\
\hline Second intervetion & 3.00 & 1.60 & $37.3 \%$ & 4.1 & 1.73 & $51.43 \%$ \\
\hline
\end{tabular}

At the end of the first intervention, we provide a Survey to get feedback on some problems faced by the participants during the application. As for the difficulty of the questions, $52.4 \%$ of the participants found the same level of difficulty in both methods. Among the preference for the two methods, $61.90 \%$ of them found it better to answer the questions by Kahoot. Among the difficulties found in Kahoot, $38.10 \%$ of the participants felt pressed for time pre-determined by the tool to answer each question; about $33 \%$ of the participants had difficulties in marking the alternatives, and $4.80 \%$ assumed that visualizing the issues was the main problem. Moreover, for $23.8 \%$ of the participants, there were no problems.

Between the first and the second intervention, we noticed a difference in the participants' behaviour. It is interesting to note that, at Kahoot, students were more accustomed to using the tool, as it alleviated the problems that occurred in the first intervention. We observed that the participants did not complain about accidentally checking the alternatives. Moreover, as there was a reduction in the number of questions administered, students felt less pressed for time.

The application promoted with Kahoot in the first intervention made the participants more motivated to want to overcome their results. The participants were more agitated, pointed out colleagues who would be favourites to reach the top of the leaderboard, and set goals to the position in the table to be in the top five.

Through the quick feedback provided by the Kahoot tool, we noticed a more significant interaction between the student and the teacher. In the paper-and-pencil application method, this interaction was not as visible. At the end of this intervention, we applied another Survey, using the google forms form.

Regarding the difficulty of the questions, $59.10 \%$ of the participants noted that the questions administered in the paper-and-pencil method were more difficult when compared to Kahoot. We noticed a preference for the 70\% Kahoot among the participants. About $95.5 \%$ were more excited when answering questions when compared to paper-andpencil, and 59.10\% felt more comfortable using Kahoot to answer the questions. Also, for 90.9\% of participants, they believe that Kahoot can better encourage students to want to study. The teacher of the discipline already expected this behaviour from the participants since she already adopts gamified strategies in the classroom, such as math games and dynamic competitions.

\section{Method}

At the end of the two interventions carried out, we applied a Survey with the students who participated in the Experience Report. We analyzed whether the usability of a gamified 
assessment instrument is better compared to the traditional model with paper and pencil, according to the participants' point of view.

We adapted the questionnaire applied in the study by [Lund 2001], which aims to measure the usability of a product, tool, or application. The metrics evaluated are Usefulness, Ease of use, use of learning, and Satisfaction.

Usefulness - which aims to analyze the Usefulness and effectiveness of each application method. Ease of use - its purpose is to check the issue of Ease of use and availability regarding each tool. Use of learning - aims to ascertain the Ease of learning to each instrument. Satisfaction - in order to measure the level of user satisfaction in using the two tools.

Each participant who participated in at least one of the interventions answered a Survey. The participant responded by evaluating the two methods applied, the first aimed at evaluating the Kahoot tool, based on the four metrics described previously, and the second on the same model, changing only the context for the application method carried out through the paper-and-pencil. The evaluation performed by each participant was made according to a Likert scale: $1=$ strongly disagree, $2=$ partially disagree, $3=$ neither agree nor disagree $4=$ partially agree, and $5=$ strongly agree.

The data collected by the Survey was of the numerical type of quantitative order, where stores in spreadsheets separating the elements according to each application context - gamified using Kahoot and the traditional method performed with Paper-and-pencil.

We analyzed these data using the Wilcoxon test, which is a non-parametric method that compares two samples in order to verify whether there is a distinction between the two results. According to the test result, if the p-value is less than 0.05 of significance, then the null hypothesis must be refuted, that is, that there are differences between the methods evaluated in question. Otherwise, there is no relevant difference between the methods analyzed.

\section{Results and discussions}

In this section, we present/discuss the results obtained with the application of a Research focused on the usability of the Instrument application with/without leaderboards. We present the results in Table 2 .

In Usefulness, it is possible to verify that there is no significant difference in the questions of effectiveness and Usefulness of Kahoot to the application method carried out with paper-and-pencil, considering that the latter is commonly used in the classroom and the realization of the ENEM. However, in terms of time, it was found that the Kahoot tool saves more time compared to paper-and-pencil. In the students' view, the paper-andpencil application method takes longer to the performance of the gamified application.

In Ease of use, there is a significant difference in terms of Ease of use, according to the students' opinion, the Kahoot tool is easy to use to the method applied with paperand-pencil. On the other hand, Kahoot presented a lower performance when compared to the paper-and-pencil method in terms of use, since Kahoot needs mobile devices and an Internet connection. 
Table 2. Analysis of results on the opinion of professionals in relation to the USE framework

\begin{tabular}{|l|c|c|c|c|c|}
\hline \multirow{2}{*}{ USE Framework } & \multicolumn{2}{|c|}{ Paper-and-Pencil } & \multicolumn{2}{c|}{ Kahoot } & \multirow{2}{*}{ P-value } \\
\cline { 2 - 5 } & Average & Sd & Average & Sd & \\
\hline Usefulness & $\mathbf{3 . 7 7 7}$ & - & $\mathbf{4 . 3 8 9}$ & - & - \\
\hline Is Instrument useful? & 4.333 & 1.018 & 4.521 & 0.989 & 0.355 \\
\hline Is Instrument effective? & 4.104 & 0.881 & 4.417 & 0.871 & 0.077 \\
\hline Does Instrument save time? & 2.896 & 1.077 & 4.229 & 0.805 & 0 \\
\hline Ease of Use & $\mathbf{4 . 0 0 0}$ & - & $\mathbf{4 . 3 4 3}$ & - & - \\
\hline Is Instrument easy to use? & 4.083 & 0.919 & 4.729 & 0.494 & 0 \\
\hline $\begin{array}{l}\text { The Instrument can be used } \\
\text { successfully every time? }\end{array}$ & 3.917 & 1.108 & 3.958 & 0.944 & 0.841 \\
\hline Ease of Learning & $\mathbf{4 . 1 5 2}$ & - & $\mathbf{4 . 5 0 0}$ & - & - \\
\hline Did I learn to use it quickly? & 4.229 & 0.994 & 4.625 & 0.703 & 0.023 \\
\hline $\begin{array}{l}\text { Is it easy to remember how you } \\
\text { use Instrument? }\end{array}$ & 4.521 & 0.850 & 4.708 & 0.651 & 0.220 \\
\hline $\begin{array}{l}\text { Did I quickly become adept at } \\
\text { using Instrument? }\end{array}$ & 3.708 & 1.336 & 4.167 & 1.108 & 0.056 \\
\hline Satisfaction & $\mathbf{3 . 5 0 5}$ & - & $\mathbf{4 . 6 2 2}$ & - & - \\
\hline Am I satisfied with Instrument? & 3.830 & 1.020 & 4.520 & 0.830 & 0 \\
\hline $\begin{array}{l}\text { Would I recommend Instrument } \\
\text { to a friend? }\end{array}$ & 3.810 & 1.100 & 4.650 & 0.670 & 0 \\
\hline Is Instrument pleasant to use? & 3.650 & 1.190 & 4.690 & 0.660 & 0 \\
\hline Is Instrument fun? & 2.730 & 1.300 & 4.630 & 4.630 & 0 \\
\hline
\end{tabular}

In Ease Learning, there is a significant difference in the speed of learning the gamified method, and the students assumed that they learned to use the Kahoot tool quickly compared to the method applied with paper-and-pencil. The competence to memorize the use of the resources of each tool and the ability to become a specialist in the use of them does not demonstrate relevant differences between the two methods applied, according to the data, the Kahoot tool does not surpass these points in comparison to the method of an application made with paper-and-pencil.

In Satisfaction, the level of Satisfaction of the gamified tool is higher and more significant than the traditional evaluation model. Participants would recommend Kahoot to a friend and found the tool fun and enjoyable.

\section{Conclusions}

In this paper, we conducted a case study with students of the third year of high school in the discipline of Mathematics. We analyzed the participation of these students, using ENEM questions and adopting the application methods - Kahoot and paper-and-pencil. We developed a Survey and analyzed the usability requirements of the two application methods according to the participant's vision.

We found that Kahoot, compared to paper-and-pencil, saves more time, is easy to use, and promotes a higher level of satisfaction among students. The participants considered the use of Kahoot to be more comfortable, exciting, satisfying, and 
encouraging learning better than the paper-and-pencil method. Given this, the main contribution of this study was to gamify a high school classroom using ENEM questions in the discipline of mathematics, as well as to present the teacher with new teaching methods with the inclusion of technologies contributing to the teaching-learning process.

\section{References}

Brasil (2018). Sistema de avaliação da educação básica. Disponível em: http://portal.mec.gov.br. Acesso em: 30 maio 2019.

Deterding, S., Dixon, D., Khaled, R., and Nacke, L. (2011). From game design elements to gamefulness: defining gamification. In Proceedings of the 15th international academic MindTrek conference: Envisioning future media environments.

Fardo, M. L. (2013). A gamificação aplicada em ambientes de aprendizagem. Revista Novas Tecnologias na Educação, 11(1).

Kahoot (2019). Kahoot' home sreen. Disponível em: https://kahoot.com/. Acesso em: 20 de maio de 2019.

Lima, L. (2018). Um desafio no aprendizado da matemática do ensino médio: soma de números fracionários. Trabalho de Conclusão de Curso - Universidade do Estado do Amazonas, Parintins-AM.

Lund, A. (2001). Measuring usability with the use questionnaire. Usability and user experience newsletter, 8(2).

Nascimento, F. M. L. (2018). Proposta de aulas lúdicas com o auxílio da tecnologia kahoot! no ensino da matemática. Trabalho de Conclusão de Curso - Universidade do Sul de Santa Catarina, Tubarão/SC.

Pereira, I. B., Santos, J. S., and Suárez, P. (2019). Análise de uma aplicação gamificada para o aprendizado de matemática discreta. In Proceeding of the 30th Brazilian Symposium on Computers in Education.

Rosa, R. (2013). Trabalho docente: dificuldades apontadas pelos professores no uso das tecnologias. In I Encontro de Pesquisa em Educação e Congresso Internacional de Trabalho Docente e Processos Educativos.

Silva, J. B., Andrade, M. H., Oliveira, R. R., Sales, G. L., and Alves, F. R. V. (2018). Tecnologias digitais e metodologias ativas na escola: o contributo do kahoot para gamificar a sala de aula. Revista Thema, 15(2).

Wiener, A. and Campos, A. (2018). Colligo app: gamificação em sala de aula. In Proceeding of the 7th Brazilian Congress of Informatics in Education. 